\title{
Psychoanalytic Understanding and It's Therapeutic Application of Schizoid Personality
}

Kyung Kyu Lee

Department of Psychiatry, Dankook University Hospital, Cheonan, Korea

자기애성 인격장애에 대한 대상관계이론

이 경 규

단국대학교병원 정신건강의학과

Psychoanalysis 2019;30(4):98-105

https://doi.org/10.18529/psychoanal.2019.30.4.98

국문제목에 오류가 있어 수정합니다. 수정내용은 아래와 같습니다.

자기애성 인격장애에 대한 대상관계이론 $\rightarrow$ 조현성 인격장애의 정신분석적 이해와 치료적 적용

This is an Open Access article distributed under the terms of the Creative Commons Attribution Non-Commercial License (https://creativecommons.org/licenses/by-nc/4.0) which permits unrestricted non-commercial use, distribution, and reproduction in any medium, provided the original work is properly cited. 